\title{
Molecular investigation of proteinase inhibitor (PI) gene in tomato plants induced by Meloidogyne species
}

Refik Bozbuga

\begin{abstract}
Background: The plant parasitic nematode genus Meloidogyne parasitize almost all flowering crops. Plants respond with a variety of morphological and molecular mechanisms to reduce the effects of pathogens. Proteinase inhibitors (PI), a special group of plant proteins which are small proteins, involve in protective role in the plants attacked by microorganisms. Still, the plant response using PI against nematodes has not been well understood. Therefore, this study was aimed to determine the expression of proteinase inhibitor I (PI-I) gene subsequent the infection of $M$. incognita, M. javanica, and M. chitwoodi in tomato plants post nematode infections. Molecular methods were used to determine the Pl gene expressions at different days post nematode infections in host tissues.

Results: Results revealed that the population of $M$. incognita species reached the highest level of nematode population followed by M. javanica and M. chitwoodi, respectively. All Meloidogyne species induced expression of PI-I gene reached at the utmost level at 3 days post infection (dpi) in host tissues. Relative gene expression level was sharply dropped at $7 \mathrm{dpi}, 14 \mathrm{dpi}$, and $21 \mathrm{dpi}$ in $M$. incognita induced gene expression in host tissues. Similar results were observed in host tissues after infection of M. javanica and M. chitwoodi.

Conclusions: The commonalities of plant response across a diverse Meloidogyne species interaction and the expression of PI gene may be related to plant defense system. Increased level of PI gene expressions in early infection days in host tissues induced by parasitic nematodes may share resemblances to the mechanisms of resistance on biotrophic interactions.
\end{abstract}

Keywords: Gene expression, Proteinase inhibitors I gene, nematode, Tomato, Meloidogyne incognita, Meloidogyne javanica, Meloidogyne chitwoodi

\section{Background}

Plant cell wall is important component in plant cell and plays an essential role against pathogens $[1,2]$. The modification of plant cell wall molecular architecture occurs during the nematode infection that presence and distribution of glycoproteins, pectin, and hemicelluloserelated polysaccharides have been changed in nematode feeding site [3]. A parasitic nematode group, Meloidogyne genus termed also root knot nematodes, creates a unique feeding site termed giant cell to supply nutrient

Correspondence: refikbozbuga@gmail.com

Biological Control Research Institute, Nematology Lab, 01321, Yuregir, Adana, Turkey to the nematode from plant [4]. The cell wall also has physical barriers with cellulose, hemicellulose, lignin, proteins, and chemical substances [5]. The thickness of giant cell walls are around 6 times thicker than neighboring cells walls in the nematode feeding site [4]. In addition, gall thickness also varies in different host roots. M. incognita caused gall thickness as a percentage of adjacent root thickness are 300\%, 250\%, 650\%, and 250\% thicker in maize, Arabidopsis, Aduki bean, and potato, respectively [4].

Plants give response to the nematode infection in molecular level [6-8] that proteinase inhibitors are a group of proteins that demonstrating a generally part

\section{Springer Open}

(c) The Author(s). 2021 Open Access This article is licensed under a Creative Commons Attribution 4.0 International License, which permits use, sharing, adaptation, distribution and reproduction in any medium or format, as long as you give appropriate credit to the original author(s) and the source, provide a link to the Creative Commons licence, and indicate if changes were made. The images or other third party material in this article are included in the article's Creative Commons licence, unless indicated otherwise in a credit line to the material. If material is not included in the article's Creative Commons licence and your intended use is not permitted by statutory regulation or exceeds the permitted use, you will need to obtain permission directly from the copyright holder. To view a copy of this licence, visit http://creativecommons.org/licenses/by/4.0/. 
inside the plant defense against plant feeders from insects to microorganisms. The proteinase inhibitors involve in perturbing the enzymatic capability in microbic chemicals that obtainable at intervals plant pests; hence, they might not digest plant tissues [9]. Additionally, some proteinase inhibitors involve in plant antimicrobial properties giving limitation of pathogen growth [10]. Protein inhibitors are induced mostly during wounding or chemical signalling through molecules of the plant [11]. Signal molecules involve in production and relocation of proteinase inhibitors by the phloem and xylem of the plant [11]. When an insect feed on plant, those inhibitors involve in less digestion in insect, thus the pest may not grow proper level [12].

Meloidogyne species are most important plant parasitic nematodes species causing economic losses on crops more than a 170 billion dollars in the world [13]. Around a hundred species of root-knot nematodes have been described in the world [14]. Of these species, $M$. incognita, $M$. javanica, and $M$. arenaria are tropical, $M$. hapla, M. chitwoodi, and M. fallax are temperate species [15]. M. incognita, M. javanica, M. hapla, and M. arenaria are frequently found in many countries and they are called major species [16]. Meloidogyne species are obligate sedentary endoparasites and infect plant roots. The second stage of Meloidogyne species are infective stage and enter plant roots just behind root elongation zone and move intercellularly and create a feeding site $[4,16]$. Nematode secretes effectors which are produced in gland cells and cause the formation of feeding sites [17]. Following the starting the feeding of J2s, galls are seen within days $[18,19]$. Nematode undergoes third and four stages and finally becomes an adult female. The male may leave from roots (mobile), and the adult female become sedentary and starts to produce eggs [16]. $M$. incognita hatching number of $M$. incognita increases between 25 and $35^{\circ}$ but decreases in higher temperatures above $35^{\circ} \mathrm{C}$ [20].

The generation of proteinase inhibitors reveals that plants have the capacity to modify their defense behavior in reaction to plant invaders including nematodes. This complex defense mechanism serves to protected plant from pathogens. The expression of PI-I gene during the three nematode species has been fully understood. Therefore, this study was aimed to determine PI gene expression at $1,3,7,14$, and 21 days post-infection of three different root knot nematodes (M. incognita, $M$. javanica, $M$. chitwoodi) in tomato plants.

\section{Methods}

\section{Plant and nematode culture}

Susceptible tomato (Solanum lycopersicon) plants were used in this experiment. The 25-day-old tomato seedlings were sowed in the $1 \mathrm{~kg}$ pots of sterilized soil medium. Soil medium was consisted of $80 \%$ sand $+20 \%$ garden soil. Soil medium was autoclaved to kill weed seeds, pathogen, and other microorganism in pressure sterilizer at $126{ }^{\circ} \mathrm{C}$ for an hour. This study was performed in the greenhouse. The greenhouse temperature was set up as $25 \pm 2{ }^{\circ} \mathrm{C}$ in $16 \mathrm{~h}$ light $8 \mathrm{~h}$ dark conditions with $60 \%$ of humidity conditions. When tomato seedling roots reached to the bottom of the pot, seedlings were ready to inoculate the nematodes, Meloidogyne incognita, Meloidogyne javanica, and Meloidogyne chitwoodi. The experiment was set up with five repetitions as infected and uninfected plants. Randomized complete block design for each of the experiment was set up with five replications that each plant was grown in separate pots. Two independent experiments were achieved.

The pure nematode cultures of three Root knot nematodes species, Meloidogyne incognita, Meloidogyne javanica, and Meloidogyne chitwoodi, which already exist in the greenhouse, were used for this experiment. To maintain the nematode population, pure culture of second stage juveniles were given to susceptible tomato plants at $25 \pm 2{ }^{\circ} \mathrm{C}$ at $\% 60$ humidity and $16 \mathrm{~h}$ light and $8 \mathrm{~h}$ dark conditions. Hatching was performed using Modified Baerman funnel technique. The second stage of juveniles (j2) was collected, counted, and optimized. The viability juveniles were checked under the stereo microscope. Then, the nematode infection assay was achieved. The number of second stage of nematode juveniles was calculated as $1 \mathrm{~J} 2 \mathrm{~s}$ per $\mathrm{cm}^{3}$ soil mix (1000 J2s for each pot) for assay. Two centimeters depth of four holes were opened on the on the surface of pots and in total 1000 $\mathrm{j} 2 \mathrm{~s}$ were given on holes. Pots with plants were placed for 2 months in greenhouses at $25 \pm 2{ }^{\circ} \mathrm{C}$. Nematode population was calculated among differences of initial and final nematode population. Following the nematode infection, 2 months later, infected roots with $200 \mathrm{~g}$ of soil and root samples with five repetitions for each experiment were taken. Soil and root samples were brought to the nematology lab. Nematode extraction was achieved using modified Baermann funnel method. Second stage juveniles were collected and counted under the stereo microscope. Final number of nematode populations was calculated. Variance analysis (ANOVA) was performed at $P \leq 0.05$ according to Duncan's multiple range test to determine the difference among nematode populations.

\section{Gene expression}

Tomato leaves were collected at 1, 3, 7, 14, and $21 \mathrm{dpi}$ following the nematode infections. Three bunch of leaves of five tomato plants from each replicate were placed in liquid nitrogen. GeneJET plant RNA purification mini kit (Thermo Scientific, Lithuania) was used to isolate RNA from plant tissues. Plant RNA lysis Solution was pipetted $(500 \mu \mathrm{L})$ and into $1.5 \mathrm{~mL}$ micro centrifuge 
tube. Plant tissue was weighed at $100 \mathrm{mg}$ from frozen tissue and grinding the plant tissues using mortar and pestle into the liquid nitrogen. Incubated for $3 \mathrm{~min}$ at 56 ${ }^{\circ} \mathrm{C}$ and centrifuged at 14,000 rpm for $5 \mathrm{~min}$. Supernatant was collected and transferred to the clean micro centrifuge tube, added $250 \mu \mathrm{L} 96 \%$ ethanol and mixed by using pipet. Prepared mix was transferred to the purification column inserted in a collection tube and centrifuged at $11000 \mathrm{rpm}$ for $1 \mathrm{~min}$. The flow-through solution was discarded, reassembled column and collection tube. Seven hundred micro liters of wash buffer 1 were added to the purification column and centrifuged at 11,000 rpm for $1 \mathrm{~min}$. Flow-through was discarded and purification column were placed into a clean $2 \mathrm{~mL}$ collection tube. Later, $500 \mu \mathrm{L}$ wash buffer 2 was added to purification column and centrifuged at $11,000 \mathrm{rpm}$ for $1 \mathrm{~min}$, and later flow-through solution was discarded. Then, the column re-spanned at 14,000 rpm for $1 \mathrm{~min}$ and collection tube was discarded. Purification column was transferred to a RNase-free $1.5 \mathrm{~mL}$ collection tube. Fifty microliters of nuclease-free water was added to purification column to elute RNA and centrifuged for 1 min at 11,000 rpm. Purification column was discarded, and purified RNA was used. The amount of RNA was measured in nanodrop (Maestrogen nano, Taiwan) and diluted as $1000 \mathrm{~nm}$. Then, cDNA protocols were achieved. iScript cDNA synthesis kit (Bio-Rad, USA) was used for cDNA study. The 5x i Script Reaction mix (4 $\mu \mathrm{l})$, iScript Reverse Transcriptase $(1 \mu \mathrm{l})$, Nuclease free water $(14.5 \mu \mathrm{l})$, RNA template $(0.5 \mu \mathrm{l})$ with total $20 \mu \mathrm{l}$ volume were prepared. The reaction mix was incubated in a thermal cycler using the following reaction: priming for $5 \mathrm{~min}$ at $25^{\circ} \mathrm{C}$, reverse transcription $20 \mathrm{~min}$ at $46^{\circ} \mathrm{C}$, RT inactivation for $1 \mathrm{~min}$ at $95{ }^{\circ} \mathrm{C}$. cDNAs were diluted in $1 / 10$ to use q-PCR studies. Then PCR was performed using SsaAdvanced Universal SYBR green Super mix (Bio-Rad, USA). The component of reaction (Sso advanced universal SYBR green super mix, forward and reverse primers, DNA template, nuclease-free water) was prepared in qPCR tubes.

Primers of PI-I gene sequences: Forward: 5 ' -TTGCTC TCCTCCTTTTATTTGG-3'; Reverse: 5'-GCAAGCCT TGGCATGTTC-3' were performed [21, 22]. The Solanum lycopersicon actin gene primers (Forward: 5 '-ATGT ATGTTGCCATCCAGGCT-3', Reverse: 5' -TGTGGCTG ACACGATCTCCA-3') were used as a housekeeping gene [23]. Actin gene was used as a reference gene for normalizing mRNA levels of target genes following the infection of nematodes: $M$. incognita, $M$. javanica, and $M$. chitwoodi. Thermal cycling protocol on a real-time PCR was achieved. After polymerase activation and DNA denaturation at $95{ }^{\circ} \mathrm{C}$ for $30 \mathrm{~s}$, amplifications were performed for 40 cycles at $95{ }^{\circ} \mathrm{C}$ for $15 \mathrm{~s}$ and at $60{ }^{\circ} \mathrm{C}$ for $1 \mathrm{~min}$. To check the specificity of the PCR product, the melting curves were analyzed for each data point. Repetition was performed for three samples for each treatment. Ct values were used to determine the expression levels. Relative gene expression was calculated using the $2^{\triangle \Delta} \mathrm{Ct}$ method and uninfected (control) values were subtracted from infected (nematode infected) values.

\section{Results}

Results of this study were given under the two separate subheadings that firstly determine the differences of nematode populations among three nematode populations. Secondly, gene expression of PI-I gene on tomato plants following the infection of $M$. incognita, $M$. chitwoodi, and $M$. javanica at $1,3,7,14$, and $21 \mathrm{dpi}$.

Reproduction differences of nematode population on tomato plants: This study was aimed to determine the differences in the reproduction rate of three nematode species in same host plant (tomato). Initial nematode number per pot was $1000 \mathrm{~J} 2 \mathrm{~s}$ and final population of nematodes were counted 2 months later. Results revealed that the population of all nematode species increased. Highest nematode number in per plant was determined in M. incognita species (7200 J2s) that it was statistically grouped differently compared to other species. The nematode number was $3617 \mathrm{~J} 2 \mathrm{~s}$ and $2467 \mathrm{~J} 2 \mathrm{~s}$ in M. javanica and M. chitwoodi, respectively. However, M. javanica and M. chitwoodi were placed statistically in the same group (Fig. 1). It can be said from the results that $M$. incognita parasites the tomato plant more than others.

Secondly, proteinase inhibitor I (PI-I) gene expression on tomato plants following the infection three root knot nematodes were determined. Meloidogyne incognita induced proteinase inhibitor (PI) gene expression levels in host tissues at $1,3,7,14$, and 21 dpi were given in Fig. 2. Value of relative gene expression level was 2.37 at $1 \mathrm{dpi}$ then raised and reached the highest peak at $3 \mathrm{dpi}$ (8.39). Value of relative gene expression level sharply dropped as 2.07, 0.56, and 0.29 at $7 \mathrm{dpi}, 14 \mathrm{dpi}$, and 21 dpi, respectively (Fig. 2). Meloidogyne javanica-induced proteinase inhibitor (PI) gene expression in host tissues were given in Fig. 3. The value of gene expression was 3.71 in $M$. javanica infected host tissues at $1 \mathrm{dpi}$. Gene expression level was doubled at $3 \mathrm{dpi}$ following the $1 \mathrm{dpi}$ (Fig. 3). The highest peak was observed at $3 \mathrm{dpi}$ and severely decrease of gene expression value (1.17) was observed at $7 \mathrm{dpi}$. The lowest values of gene expression following the infection of $M$. javanica were determined 14 and 21 dpis (Fig. 3). Similar trend line was observed in $M$. incognita and $M$. javanica induced PI-I gene expression value in host tissues (Figs. 2 and 3). Meloidogyne chitwoodi induced proteinase inhibitor (PI) gene expression values in host tissues at different post infections were presented in Fig. 4. The values of gene expression 


\section{Nematode population}

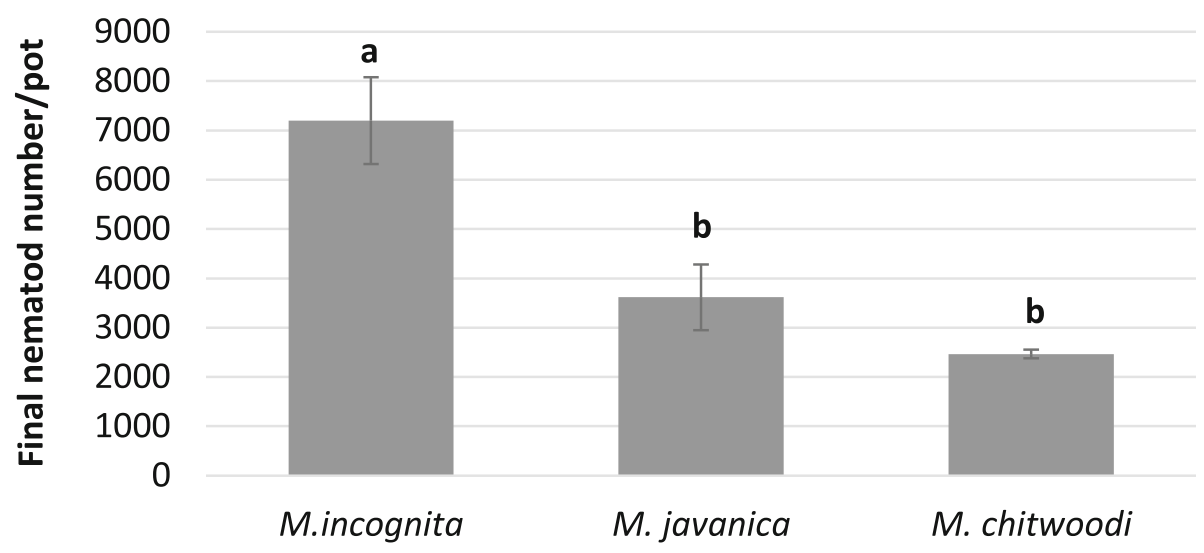

Nematod species

Fig. 1 Nematode population (reproduction) of Meloidogyne species: M. incognita, M. javanica, M. chitwoodi in the roots of tomato plants. Initial nematode number (first infection number) was 1000 nematode in each pot for each plant. Final nematode number was calculated following the 2 months later of nematode inoculation. Randomised block design was accomplished with five repetitions. $Y$ axis represents final nematode number per plant, $X$ axis indicates nematode species. Error bars represents the standard error of the means of five replicates. Letters on the column indicates the statistical differences $(P<0.05)$ among nematode populations

were 2.47 at $1 \mathrm{dpi}$ following the infection of $M$. chitwoodi. The gene expression value was observed as 15.72 at 3 dpi. Decreasing value of gene expression was observed at $7 \mathrm{dpi}$ (value 3.21), $14 \mathrm{dpi}$ (value 0.10 ), and 21 dpi (value 0.20). The peak of the polynomial trendline of the gene expression value was observed at 3 dpi following the infection of M. chitwoodi (Fig. 4). The value of gene expression at 3 dpi as the highest peak among not only the $M$. chitwoodi induced gene expression at 1, 7, 14, and 21 dpis but also other species (M. incognita and M. chitwoodi) induced gene expression values (Figs. 2, 3, and 4). The high level of gene expression at 3 dpis can be related to plant resistance against nematode because of nematode population was lowest in M. chitwoodi

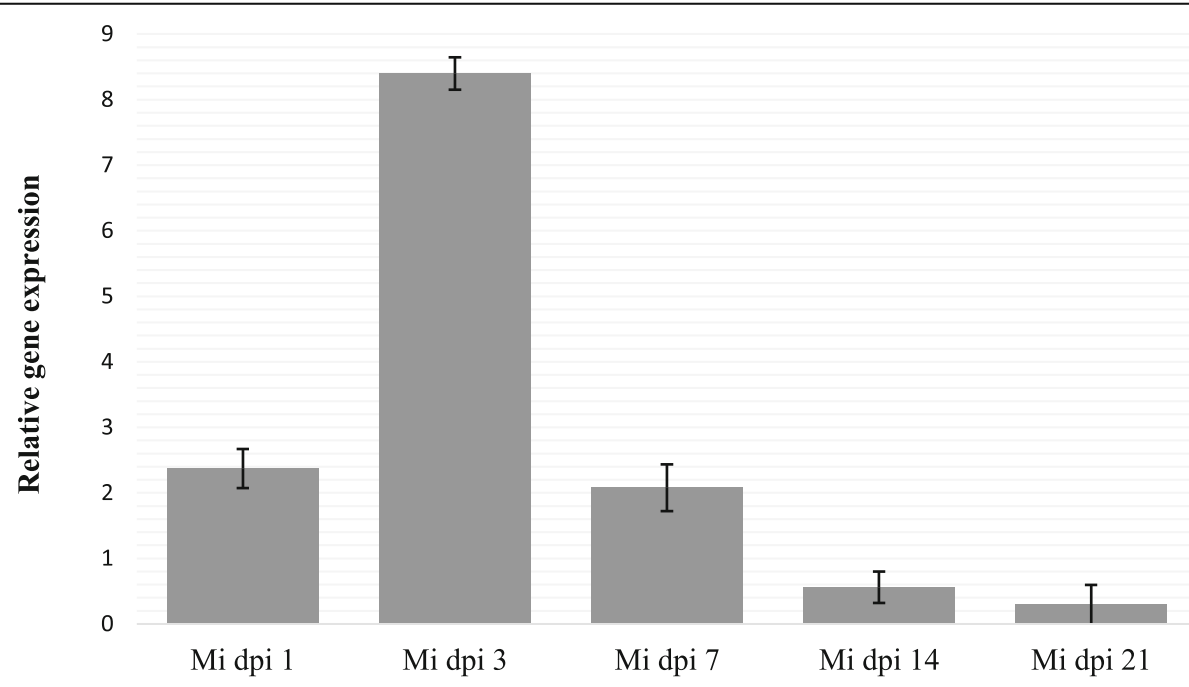

Meloidogyne incognita days post infections (dpi)

Fig. 2 Meloidogyne incognita induced proteinase inhibitor I gene expression in host tissues at different days post-infections. Housekeeping gene Actin gene was used to normalize expression of genes of interest. Relative gene expression was calculated biological replicates using the $2^{\Delta \Delta C t}$ method and uninfected (control) values were subtracted from infected values. $Y$ axis represents relative gene expressions, $X$ axis indicates $1 \mathrm{dpi}, 3$ dpi, $7 \mathrm{dpi}, 14 \mathrm{dpi}$, and $21 \mathrm{dpi}$ following Meloidogyne incognita infection. Error bars represents the standard error of the means of three replicates. Mi, Meloidogyne incognita; dpi, days post infection 


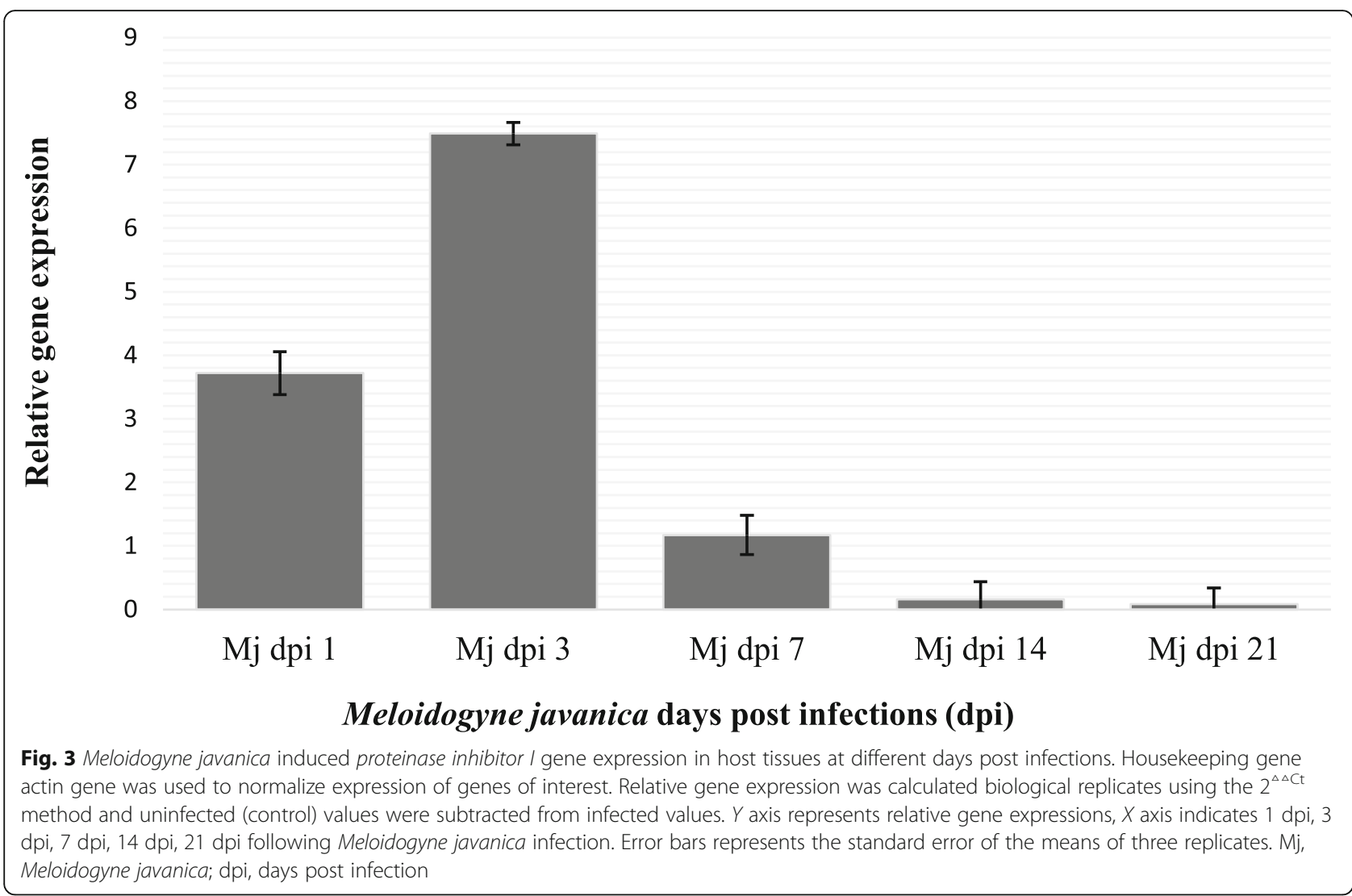

infection, however gene expression was doubled compared to values of other nematode species ( $M$. incognita, $M$. javanica) induced host plant gene expressions (Figs. 1, 2, 3, and 4). In general, PI-I gene expression was observed as the highest value at $3 \mathrm{dpis}$ at the infection of all nematode species in tomato plants (Figs. 2, 3, and 4). It may conclude that highest gene expression occurs at early dpis.

\section{Discussion}

Protease inhibitors (PIs) are small ubiquitous proteins that they have many biological functions in plants including defense against pathogens [24]. The family of Künitz protease inhibitor amasses when the stress of water occurs in leaves of Brassica napus [25]. Kunitztype potato proteinase inhibitor is localized in the cell wall, plasma membrane of cells, and non-wounded upper leaves in wounded potatoes [26]. PIs are important anti nutritive compounds to defend crop plants from the infection of plant pest or pathogens [27, 28]. Recombinant protease inhibitors are important tools for the development of insect-resistant transgenic crops [29]. Overexpression of cysteine proteinase inhibitor activity involves tolerance to abiotic stress and messenger RNAs are transported to distant tissues of Arabidopsis [30]. Proteinase inhibitors (PIs) are important elements of natural plant defense [31]. In this study, $M$. incognita, $M$. chitwoodi, and M. javanica induced gene expressions in tomato plants upregulated at 1 and 3 dpis and decreased at 7 , 14, and 21 dpis. The result of this study revealed that PIs possibly involve in defense mechanism; however, later days nematode suppressed the PIs in the plant during the plant nematode compatible interactions. The plant proteases involve in removal of protein damage and plant defense responses. A plant parasitic nematode Heterodera schactii caused to decrease of protease activities in infected roots of Arabidopsis plants. AtCYS1, AtCYS5, and AtCYS6 gene expressions increase upon $H$. schactii infection [32].

Potato cysteine proteinase inhibitor is expressed in Phythophthora resistance potato cultivar White Lady. Silencing of Potato cysteine proteinase inhibitor resulted in increase in lesion size and water soaking [33]. The potato protease inhibitor gene plays roles in the coldinduced sweetening of potato tubers by modulating invertase activity [34]. Kunitz-like inhibitors and proteinase inhibitors 1 are abundant in storage organs of potato plants and are upregulated in other tissues in response to biotic and abiotic stress. However, PI expression profiles are not correlated following the infection of a plant parasitic nematode Glabodera rostochiensis with the resistance status of the potato genotype [24]. Plant cysteine proteinase inhibitor and a fungal chitinase 


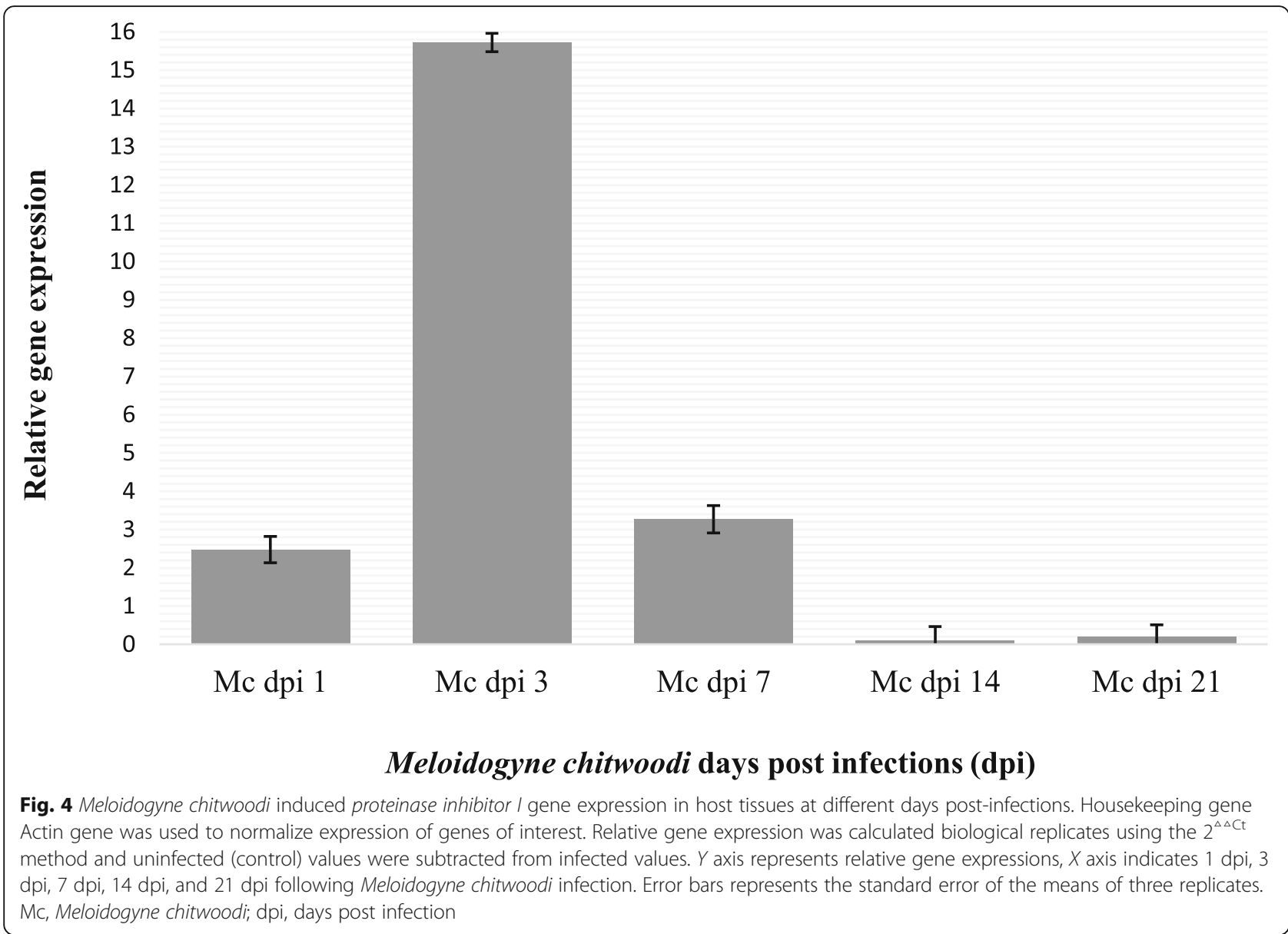

which are used to transform tomato (Solanum lycopersicum) caused to synergistic effect to defense response genes that caused to inhibitory effect on Meloidogyne incognita [35]. In this study, plant could not manage suppress the nematode feeding, therefore, this situation may lead to decrease gene expression of late dpis: 7, 14, and 21 dpis (Figs. 2, 3, and 4).

Some species of Root knot nematodes: $M$. incognita, M. javanica, M. arenaria, M. chitwoodi, M. fallax, and $M$. hapla are the most common parasitic nematode species and may found 95\% of the globe in crops [36]. Nematodes cause significant yield losses in vegetables worldwide and these losses are $42-54 \%$ in tomato [15]. $M$. incognita is placed in the top list among plant parasitic nematodes [14]. The population of $M$. incognita reproduction rate was reached at the highest level comparing other nematode species in this study (Fig. 1).

Plant response with multiple layers of defenses and triggers resistance to pathogens and Salicylic acid involves in defense response [37] and the mechanisms of systemic induced resistance have been studied by many researchers [38-40]. PIs probably involves in the defense mechanisms in early days post infection, because gene expression was reached the highest level at 1 and 3 dpis (Figs. 2, 3, and 4).

\section{Conclusions}

PI-I and II synthesis occur in leaves of wounded tomato plants [41] and PI-I involves in plant defense mechanism. In this study, PI gene involved in plant systemic induced resistance mechanism at early infection time. This revealed that the gene expression of PI shared similarities with the response of tomato to different nematode species. The gene expression commonalities across diverse nematode species in the same host may play an important role for potential wide range of molecular resistance mechanisms.

\section{Abbreviations}

cDNA: Complementary DNA; Ct: Cycle threshold; DNA: Deoxyribonucleic acid; dpi: Days post-infection; j2: Second stage of juvenile; mRNA: Messenger RNA ; PCR: Polymerase chain reaction; Pl: Proteinase inhibitor;

RNA: Ribonucleic acid; SA: Salicylic acid

Acknowledgements

Not applicable 


\section{Author's contributions}

The author performed to design the study, analysis of results and preparation of manuscript. The author read and approved the final manuscript.

\section{Funding}

Not applicable

\section{Availability of data and materials}

All data generated/analyzed during this study are included in this manuscript.

\section{Declarations}

Ethics approval and consent to participate

Not applicable

\section{Consent for publication}

Not applicable

\section{Competing interests}

The author declares that there are no competing interests.

Received: 26 May 2021 Accepted: 13 August 2021

Published online: 30 August 2021

\section{References}

1. Caffall KH, Mohnen D (2009) The structure, function, and biosynthesis of plant cell wall pectic polysaccharides. Carbohydr Res 344(14):1879-1900 https://doi.org/10.1016/j.carres.2009.05.021

2. Albersheim P, Darvill A, Roberts K, Sederoff R, Staehelin A (2011) Plant cell walls: from chemistry to biology. Garsland Science, New York

3. Bozbuga R, Lilley JL, Knox JP, Urwin PE (2018) Host-specific signatures of the cell wall changes induced by the plant parasitic nematode, Meloidogyne incognita, Sci Rep 8(1):17302. https://doi.org/10.1038/s41598-018-35529-7

4. Bozbuga R (2017). Characterisation of cell walls at the feeding site of Meloidogyne incognita, PhD thesis, University of Leeds

5. Heredia A, Jimenez A, Guillen R (1995) Composition of plant-cell walls. Zeitschrift Fur Lebensmittel-Untersuchung Und-Forschung 200(1):24-31. https://doi.org/10.1007/BF01192903

6. Bozbuga R (2020) Expressions of Pathogenesis related 1 (PR1) Gene in Solanum lycopersicum and Influence of Salicylic Acid Exposures on HostMeloidogyne incognita Interactions. Dokl Biochem Biophys 494(1):266-269 https://doi.org/10.1134/S1607672920050038

7. Bozbuga R (2020) Effect of Submerging Solanum lycopersicum Roots in Salicylic Acid (SA) Solution for Different Durations on Nematode Infection and Expressions of SIPR5 Gene. Horticultural studies 37(2):144-149 https:// doi.org/10.16882/HortiS.833488

8. Bozbuga R (2020) Genetics, molecular interactions and resistance response of common bean (Phaseolus vulgaris L.) Genotypes to Root Knot Nematodes (Meloidogyne spp). Cutting-Edge Research in Agricultural Sciences 3:78-83 Retrieved from https://stm.bookpi.org/CRAS-V3/article/ view/2535

9. Shu-Guo F, Guo-Jiang W (2005) Characteristics of plant proteinase inhibitors and their applications in combating phytophagous insects. Botanical Bull Academia Sinica 46:273-292

10. Kim JY, Park SC, Hwang I, Cheong H, Nah JW, Hahm KS, Park Y (2009) Protease inhibitors from plants with antimicrobial activity. Int J Mol Sci 10(6): 2860-2872. https://doi.org/10.3390/ijms10062860 PMC 2705521

11. Farmer EE, Ryan CA (1990) Interplant communication: airborne methyl jasmonate induces synthesis of proteinase inhibitors in plant leaves. Proc National Acad Sci 87(19):7713-7716. Bibcode:1990PNAS...87.7713F. https:// doi.org/10.1073/pnas.87.19.7713. PMC 54818

12. Lawrence $P$, Koundal K (2002) Plant protease inhibitors in control of phytophagous insects. Plant Biotechnology. 5(1). https://doi.org/10.2225/ vol5-issue1-fulltext-3 - via Electronic Journal of Biotechnology.

13. Elling AA (2013) Major emerging problems with minor Meloidogyne species. Phytopathology 103(11):1092-1102. https://doi.org/10.1094/PHYTO01-13-0019-RWW

14. Jones JT, Haegeman A, Danchin EGJ, Gaur HS, Helder J, Jones MGK, Kikuchi T, Manzanilla-Lopez R, Palomares-Rius JE, Wesemael WML, Perry RN (2013)
Top 10 plant-parasitic nematodes in molecular plant pathology. Mol Plant Pathol 14(9):946-961. https://doi.org/10.1111/mpp.12057

15. Netscher C, Sikora RA (1990) Nematode parasites on vegetables. Editted, Luc M, Sikora RA, Bridge J Plant Parasitic Nematodes in Subtropical and Tropical Agriculture. CAB International, pp 231-283

16. Moens M, Perry RN, Starr $\mathrm{L}$ (2010) Meloidogyne species - a diverse group of novel and important plant parasites. Root-Knot Nematodes 1-17

17. Hewezi T, Howe P, Maier TR, Hussey RS, Mitchum MG, Davis EL, Baum TJ (2008) Cellulose binding protein from the parasitic nematode Heterodera schachtii interacts with arabidopsis pectin methylesterase: Cooperative cell wall modification during parasitism. Plant Cell 20(11):3080-3093. https://doi. org/10.1105/tpc.108.063065

18. Bozbuga R, Dasgan HY, Akhoundnejad Y, Imren M, Toktay H, Kasapoglu EB (2015) Identification of common bean (Phaseolus vulgaris) genotypes having resistance against root knot nematode Meloidogyne incognita, Legume Res, 38: 669-674. DOI: https://doi.org/10.18805/lr.v38i5.5948

19. Bozbuga R, Imren M, Kasapoğlu EB, Toktay H, Elekcioğlu IH (2015) Determining the Optimal Meloidogyne Incognita Inoculum Level Inoculation Time, Pathogencity and Gall Development on Tomato Roots for Resistance Experiments in Breeding Programs. Vegetos 28(1):70-75 https:// doi.org/10.5958/2229-4473.2015.00010.5

20. Toktay H, Bozbuğa R, Imren M, Kasapoğlu EB, Elekcioğlu IH (2014) Meloidogyne incognita (Kofoid \& White, 1919) Chitwood ve Meloidogyne hapla (Chitwood, 1949) (Nemata: Meloidogynidae) Yumurtalarının Açılmasına Farklı Uygulamaların Etkisi ve Ikinci Dönem Larvalarının Beslenmeden Yaşayabilme Süreleri (in Turkish). Türk Tarım ve Doğa Bilimleri Dergisi 1(4):509-515

21. Young RJ, Scheuring CF, Harris-Haller L, Taylor BH (1994) An auxin-inducible proteinase inhibitor gene from tomato. Plant Physiol. 104, 2, 811, 812. https://doi.org/10.1104/pp.104.2.811

22. Campos ML, de Almeida M, Rossi ML, Martinelli AP, Junior CGL, Figueira A, Rampelotti-Ferreira FT, Vendramim JD, Benedito VA, Peres LEP (2009) Brassinosteroids interact negatively with jasmonates in the formation of anti-herbivory traits in tomato. J Exp Bot 60(15):4347-4361 https://doi.org/1 0.1093/jxb/erp270

23. Chinnapandi B, Bucki P, Miyara SB (2017) SIWRKY45, nematode-responsive tomato WRKY gene, enhances susceptibility to the root knot nematode; $M$. javanica infection, Plant Signal Behav 2017;12, 12, e1356530. https://doi. org/10.1080/15592324.2017.1356530

24. Turra D, Bellin D, Lorito M, Gebhardt C (2009) Genotype-dependent expression of specific members of potato protease inhibitor gene families in different tissues and in response to wounding and nematode infection. J Plant Physiol 166(7):762-774. https://doi.org/10.1 016/j.jplph.2008.10.005

25. Downing WL, Mauxion F, Fauvarque MO, Reviron MP, de Vienne D, Vartanian N, Giraudat J (1992) A Brassica napus transcript encoding a protein related to the Kunitz protease inhibitor family accumulates upon water stress in leaves, not in seeds. Plant J 2(5):685-693. https://doi.org/10.1 046/j.1365-313X.1992.t01-11-00999.x

26. Suh SG, Cho JK, Suh EJ, Chung HD, Hannapel DJ (1999) Immunocytochemical intracellular localization of the 22-ku Kunitz-type potato proteinase inhibitor in potato tubers and leaves. J Plant Physiol 155(4-5):533-537 https://doi.org/10.1016/S0176-1617(99)80050-9

27. Michaud D (2000) Recombinant protease inhibitors in plants. Georgetown, Landes Bioscience. 241 pages, ISBN 1587060078

28. Haq SK, Atif SM, Khan RH (2004) Protein proteinase inhibitor genes in combat against insects, pests, and pathogens: natural and engineered phytoprotection. Arch Biochem Biophys 431(1):145-159. https://doi.org/10.1 016/j.abb.2004.07.022

29. Khalf M, Goulet C, Vorster J, Brunelle F, Anguenot R, Fliss I, Michaud D (2010) Tubers from potato lines expressing a tomato Kunitz protease inhibitor are substantially equivalent to parental and transgenic controls. Plant Biotechnol J 8(2):155-169. https://doi.org/10.1111/j.14677652.2009.00471x

30. Thieme CJ, Rojas-Triana M, Stecyk E, Schudoma C, Zhang W, Yang L, Minambres M, Walther D, Schulze WX, Paz-Ares J, Scheible WR, Kragler F (2015) Endogenous Arabidopsis messenger RNAs transported to distant tissues. Nature Plants 1(4):15025. https://doi.org/10.1038/nplants.2015.25

31. Ryan CA (1990) Protease inhibitors in plants: genes for improving defenses against insects and pathogens. Annu Rev Phytopathol 28(1):425-449 https://doi.org/10.1146/annurev.py.28.090190.002233 
32. Labudda M, Różańska E, Szewińska J, Sobczak M, Dzik JM (2016) Protease activity and phytocystatin expression in Arabidopsis thaliana upon Heterodera schachtii infection. Plant Physiol Biochem 109:416-429. https:// doi.org/10.1016/j.plaphy.2016.10.021

33. El-Banna A, Taller J (2017) Functional characterization of the silenced potato cysteine proteinase inhibitor gene (PCPI) in Phytophthora infestans resistance. Physiol Mol Plant Pathol 100:23-29 https://doi.org/10.1016/j. pmpp.2017.05.002

34. Liu X, Cheng S, Liu J, Ou Y, Song B, Zhang C, Lin Y, Li XQ, Xie C (2013) The potato protease inhibitor gene, St-Inh, plays roles in the cold-induced sweetening of potato tubers by modulating invertase activity. Postharvest Biol Technol 86:265-271 https://doi.org/10.1016/j.postharvbio.2013.07.001

35. Chan YL, Yang AH, Chen JT, Yeh KW, Chan MT (2010) Heterologous expression of taro cystatin protects transgenic tomato against Meloidogyne incognita infection by means of interfering sex determination and suppressing gall formation. Plant Cell Rep 29(3):231e238-231e238. https:// doi.org/10.1007/s00299-009-0815-y

36. Trudgill DL, Blok VC (2001) Apomictic polyphagous root knot nematodes: exceptionally successful and damaging biotrophic root pathogens. Annu Rev Phytopathol 39(1):53-77. https://doi.org/10.1146/annurev.phyto.39.1.53

37. Nishimura MT, Dangl JL (2010) Arabidopsis and the plant immune system. Plant J 61:1053-1066. https://doi.org/10.1111/j.1365-313X.2010.04131.x

38. Sticher L, Mauch-Mani B, Metraux JP (1997) Systemic acquired resistance. Annu Rev Phytopathol 35(1):235-270 https://doi.org/10.1146/annurev. phyto.42.040803.140421

39. Pieters CMJ, Van Loon LC (1999) Salicylic acid-independent plant defence pathways. Trends Plant Sci 4(2):52-58. https://doi.org/10.1016/S1360-13 85(98)01364-8

40. Durrant WE, Dong X (2004) Systemic acquired resistance. Annu Rev Phytopathol 42(1):185-209. https://doi.org/10.1146/annurev.phyto.42.04 0803.140421

41. Graham JS, Pearce G, Merryweather J, Titani K, Ericsson LH, Ryan CA (1985) Wound-induced proteinase inhibitors from tomato leaves. II. The cDNAdeduced primary structure of pre-inhibitor II. J Biol Chem 10;260(11):6561-4. PMID: 3838986

\section{Publisher's Note}

Springer Nature remains neutral with regard to jurisdictional claims in published maps and institutional affiliations.

\section{Submit your manuscript to a SpringerOpen ${ }^{\circ}$ journal and benefit from:}

- Convenient online submission

- Rigorous peer review

- Open access: articles freely available online

- High visibility within the field

- Retaining the copyright to your article

Submit your next manuscript at $\boldsymbol{\nabla}$ springeropen.com 